\begin{tabular}{|l|l|l|}
\hline \multicolumn{2}{|c|}{ PublisherInfo } \\
\hline \hline PublisherName & $:$ & BioMed Central \\
\hline \hline PublisherLocation & $:$ & London \\
\hline \hline PublisherImprintName & $:$ & BioMed Central \\
\hline \hline
\end{tabular}

\title{
Imprinting with insulation
}

\begin{tabular}{|l|l|l||}
\hline \multicolumn{2}{|c||}{ ArticleInfo } \\
\hline \hline ArticleID & $:$ & 3692 \\
\hline \hline ArticleDOI & $:$ & $10.1186 /$ gb-spotlight-20000531-02 \\
\hline \hline ArticleCitationID & $:$ & spotlight-20000531-02 \\
\hline \hline ArticleSequenceNumber & $:$ & 129 \\
\hline \hline ArticleCategory & $:$ & Research news \\
\hline ArticleFirstPage & $:$ & 1 \\
\hline \hline ArticleLastPage & $:$ & 2 \\
\hline \hline & $:$ & RegistrationDate : 2000-05-31 \\
ArticleHistory & $:$ & OnlineDate \\
\hline \hline ArticleCopyright & $:$ & BioMed Central Ltd2000-05-31 \\
\hline \hline ArticleGrants & $:$ & \\
\hline \hline ArticleContext & $:$ & 130591111 \\
\hline \hline
\end{tabular}




\section{William Wells}

Email: wells@biotext.com

On the chromosome inherited from the mother, the mammalian $H 19$ gene is active even as the upstream $\operatorname{Ig} f 2$ gene is silenced. The reverse pattern of expression occurs on the paternal chromosome. Paternal $H 19$ expression is silenced by promoter methylation, whereas paternal $\operatorname{Ig} f 2$ expression relies on an enhancer located downstream of H19. In the 25 May Nature Bell and Felsenfeld, and Hark et al., find that, on the maternal chromosome, the enhancer's access to the Igf 2 promoter is blocked by an intervening insulator (Nature 2000, 405:482-485; 486-489). This block is effected by the binding of the zinc-finger protein CTCF to the hypomethylated maternal insulator. The paternal insulator, however, is methylated and therefore does not bind CTCF or block interactions between the enhancer and the Igf2 promoter.

\section{References}

1. Deletion of the H19 differentially methylated domain results in loss of imprinted expression of H19 and $\operatorname{Igf} 2$.

2. Nature magazine hompeage, [http://www.nature.com/nature/] 